\title{
Complement control in Turkish
}

\section{Szymon Słodowicz}

\author{
Christian-Albrechts-Universität Kiel
}

\section{Introduction ${ }^{*}$}

Complement control is a well-known phenomenon in Turkish linguistics, and different proposals for analysing it are available. The majority of these treat control as a structural phenomenon, cf. Kerslake (1987), Özsoy $(1987 ; 2001)$ and Kural (1998). In sum, control is predicted only in sentences with complement clauses formed with the suffixes $-m E k$ and $-m E$, which can be case-marked, but the appearance of a possessive marker definitely precludes control. As far as the control relations are concerned, the research so far has attested the classical cases of subject and object control. In addition to that, variable control is discussed by Taylan (1996). The status of the controlled element is discussed by Bozşahin (in press), which concludes that the syntactic subject is appointed by this function in Turkish.

In this paper I will argue that the currently established approach to control is insufficient. The shortcomings of a strictly configurational approach become clear if a broader perspective on control is adopted. I follow the approach to control outlined by Stiebels (this volume), and show that two types of control must be distinguished. Inherent control is encoded in the lexical entry of the verb. Verbs which show inherent control either select only control-inducing structures or trigger control in environments not requiring control. Structural control, on the other hand, arises through the use of a control-inducing structure with a verb which does not inherently require control. Structural control verbs show control only with control-inducing structures. No control occurs with such verbs in other configurations. The data discussed in this paper will show that control is a 'mixed' phenomenon, since it may arise structurally or semantically. Its explanation must therefore consider the semantics of the relevant matrix verbs and the syntactic properties of complement clauses on an equal basis.

The paper is composed in the following way. Section 2 outlines the theoretical assumption guiding this analysis. Section 3 presents the relevant facts about

* This research was funded by the German Science Foundation (STI 151/2-2) as part of the research project 'Typology of control verbs'. I wish to express my gratitude to my colleagues Barbara Stiebels and Thomas Gamerschlag for the valuable comments and inspiring discussion. I would to thank Geoffrey Haig for his help on details of Turkish grammar. Bülent Suad-Engüzel, Murat Özkovalak and Ümit Demir provided the grammaticality judgments of the data discussed in this paper, for which I am very grateful. The responsibility for all mistakes is of course mine. 
complementation in Turkish, and provides a description of basic properties and the distribution of complement clauses, discusses the formation of control predicates and indicates some problems in providing exhaustive lists of control verbs in Turkish. The investigation of domain of control is carried out in section 4. In particular, the distinction between control-inducing and non-control-inducing structures in Turkish is elaborated in this section. The roles of controllee and controller are discussed in section 5. This section shows how the syntax and the lexicon interact in control constructions. The classification of control verbs is the crucial point made in this paper. A classification of inherent and structural control verbs is provided in section 6 .

\section{Theoretical assumptions}

In this paper I will distinguish between individual and state-of-affairs arguments (SOA-arguments in the following). Simplifying somewhat, the former take individuals as their referents, whereas the latter denote states of affairs, which includes activities, states, etc. I will furthermore distinguish between twoplace and three-place verbs with SOA-argument.

In this study I follow the semantic definition of control proposed by Stiebels (this volume), where control is defined as in (1).

(1) Obligatory control following Stiebels (this volume)

Obligatory control applies to structures in which a predicate $\mathrm{P}_{1}$ selects an SOA-argument and requires one of its (individual) arguments to be (improperly) included in the set of referents of an argument of the embedded predicate $\mathrm{P}_{2}$ heading the SOA-argument.

Following (1), the crucial feature of control is the obligatory co-reference of two arguments in a complex sentence. It must be noted that this definition imposes no explicit requirement with regard to the structure of the whole construction and the status of the arguments involved in this relation. Through its underspecification in these respects, it allows for the inclusion of a wider range of data not considered by other approaches. For instance, it does not narrow control only to the cases of subject and object control, as is the case in the proposals of Williams (1980) and Hornstein (1999), but also includes non-exhaustive readings, in the vein of Landau (2000) or Culicover \& Jackendoff (2005).

As defined above, control is a relation of obligatory co-reference between two arguments. The arguments involved in this relation will be called the controller and the controllee. The controller is the argument providing the reference for the controllee. In the majority of languages, the controller is an overt matrix clause argument, whereas the controllee is an implicit argument of the complement predicate. Polinsky \& Potsdam (2002) propose an analysis of a 
construction in Tsez in which the opposite seems to be the case. Since such constructions are not attested in Turkish, they are not considered here.

As will be shown in more detail below, control is a mixed phenomenon. It may arise lexically or syntactically; the notions of inherent and structural control capture this difference. Inherent control is triggered lexically. Verbs showing inherent control will require the co-reference of their arguments regardless of the realization of the SOA-argument. With these verbs, control is clearly lexically motivated. Structural control, on the other, arises only in particular syntactic configurations. Verbs with structural control do not inherently require coreference; instead they possess only a control potential which is activated by a particular type of the SOA-argument. With such verbs, control is motivated by the syntactic configuration.

There is another distinction relevant for the analysis of control, namely that between control-inducing and control-neutral structures. Control-inducing structures are those structures whose use in complementation presupposes control. Infinitive clauses, which cannot express their highest arguments, provide a well-known example of a control-inducing structure. Embedding such forms requires the identification of the highest argument with one of the matrix clause arguments, i.e. control. Stiebels (this volume) lists serial verb constructions and verb incorporation as further examples of control-inducing structures. The use of control-neutral structures, on the other hand, does not presuppose control. Such structures are not dependent on argument identification. Prominent examples of control-neutral structures are finite clauses and nominalizations.

Assuming the notions of inherent and structural control as well as the notions of control-inducing and control-neutral structures, it is possible to develop a more fine-grained approach to control than those which are concerned exclusively with control in control-inducing structures. In the following I will show on the basis of data from Turkish that a more fine-grained approach is necessary to adequately describe and analyse control constructions.

\section{Complementation in Turkish}

\subsection{Types of clauses used in complementation}

As is well-known, Turkish makes intensive use of nominalizations in subordination. ${ }^{1}$ Although Turkish has a wide range of suffixes which derive nouns from verbs, only a handful of them form verbal nouns which function as predicates in complement clauses. These forms share some features, which are listed in Haig

1 I neglect here the complement clauses introduced by $-k i$ because they are not used very extensively, cf. Kornfilt (1997:46). 
(1998:33-34). They retain the ability to bear valency-changing morphology, i.e. these verbal nouns allow for the passive or causative suffixes. The predicates in nominalized complements retain the ability to express negation. They govern the full range of arguments and allow modification by means of adverbials of manner. Finally, the internal order of the constituents in clauses headed by verbal nouns is free to a considerable extent, and may be altered for the purpose of information structure.

Following these lines, I will consider four types of clauses given in examples (4) to (7). Although the borderline between arguments and adjuncts is not satisfactorily well-defined, I assume that a distinction can be made. Consequently, clauses which do not encode arguments are not considered. ${ }^{2}$

$$
\begin{aligned}
& \text { _i [_i Çay iç-mek] isti-yor-um } \\
& \text { tea.NOM drink-INF want-PROG-1SG }
\end{aligned}
$$

Clauses formed with the suffix $-m E K$ denote, as Lewis (2000) puts it, express pure undefined action. Therefore no information about temporal identification of the SOAs denoted by the complement predicate is given. These clauses can be used as complements, but also are found in purpose clauses; this use is demonstrated in (5). In this example, the postposition icin for heads the infinitival clause, which expresses the purpose of the action denoted by the finite predicate.

$$
\begin{aligned}
& \text { Bu-nu [sen-i kurtar-mak için] yap-tı-m. } \\
& \text { this-DAT 2SG-ACC rescue-INF for do-PST-1SG } \\
& \text { 'I did it to rescue you.' }
\end{aligned}
$$

Clauses formed with the suffix $-m E$ are used in complementation to a greater extent, cf. (6). They have a similar meaning as the forms described above, and in fact a distinction between them is often difficult to motivate. The complement predicate in (6) exhibits the dative case and the 3SG possessive marking, which is optional depending on the matrix verb.

$$
\begin{array}{llll}
\text { Ben }_{\mathrm{i}} \quad \text { oo-nun }_{\mathrm{j}} \text { piyano } & \text { cal-ma-Sin]-a } & \text { bay1l-1yor-um } \\
\text { 1SG } 3 \text { SG-GEN } & \text { piano } & \text { play-INF-3SG.P-DAT } & \text { love-PROG-1SG } \\
\text { 'I like his playing the piano.' (Taylan 1996:58) } &
\end{array}
$$

Complements formed with the suffix $-E c E K$ denote SOAs that are intended to occur in the future, i.e. in (7) the act of getting the money is posterior to the time

2 The data are presented according to the following guidelines. Complement clauses are indicated by square brackets. Missing arguments are indicated by the symbol ', '. Referents of arguments are indicated by indices. Co-reference is indicated by the same index on two arguments. These guidelines do not have any theoretical implications. In particular I do not assume any covert elements active in the syntax. 
of utterance. They must be marked for the possessor agreement and case, as the example in (7) demonstrates. Complements formed with the suffix $-E c E K$ may be used attributively, but do not appear in purpose clauses, cf. (8).
Nurhan $_{i}$ Sevgi'ye $_{j}\left[{ }_{i} / \mathrm{j}\right.$ para al-acağ-1n]-1
bil-dir-di.
N. S.-DAT money get-GER-3SG.P-ACC know-CAUS-PST.3SG
'Nurhan informed Sevgi that (s)he would get the money.'

[Yap-acağ-1m] çok şey var.
do-GER-1SG much thing exist
'I've got a great deal to do.'

Predicates formed with the suffix $-D I K$ show the same properties, i.e. they must be marked for possessor agreement and case. They encode SOAs that are assumed to have taken place prior to the time of utterance, and are often called factive. The example in (9) demonstrates this. Furthermore, as nouns formed with $-E c E K$, they can be used attributively and do not appear in purpose clauses.

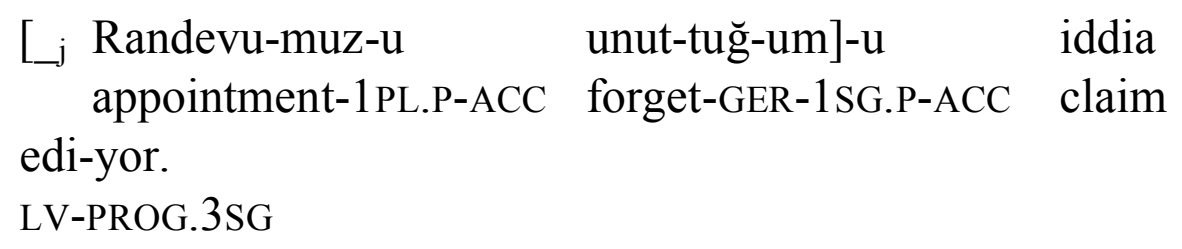

'She/he claims that I forgot our appointment.' (Göçmen et al. 1995:31)

There is some disagreement with respect to the labelling of the forms presented above. In this paper I will follow Kural (1998), and use the term infinitive for the complements formed with the suffixes $-m E K$ and $-m E$. Due to the fact that these forms receive case, I will refer to them as nominalized infinitives. Complements formed with the suffixes $-D I K$ and $-E c E K$ forms will be termed as gerunds. I treat the fact that these forms are in complementary distribution to the nominalized infinitives in purpose and relative clauses as a piece of evidence in support for these labels.

\subsection{Case marking}

Phrases that express SOA-arguments are usually case-marked. The case marking is not obligatory only with two verbs: istemek 'want' and 'bilmek' know, be able as reported by Taylan (1984:115). Otherwise, complement clauses of all types are required to take overt case. The case suffixes are given in Table 1 illustrated with the nouns $e v$ 'house' and kapl 'door'. 
Table 1: Case marking in Turkish

\begin{tabular}{|lll|}
\hline Case & Suffix & Examples \\
NOM & $\varnothing$ & ev, kap1 \\
ACC & $-y \mathrm{I}$ & ev-i, kap1-y1 \\
DAT & $-y E$ & ev-e, kap1-ya \\
LOC & -DE & ev-de, kap1-da \\
ABL & -DEn & ev-den, kap1-dan \\
GEN & $-(n)$ In & ev-in, kap1-n1n \\
\hline
\end{tabular}

Due to the case marking of SOA-arguments and the phenomenon of velar lenition (Sezer 1981), where final $/ \mathrm{k} /$ becomes $/ \varnothing /$ or a glide $/ \mathrm{j} /$, which is orthographically represented by $\breve{g}$, there are some problems with distinguishing between the complements formed with the suffixes $-m E K$ and $-m E$ if they are marked for the dative and accusative case. The judgments of my informants with respect to the written material was that the $-m E K$ forms are more formal in comparison to the $-m E$ forms. In colloquial speech, these forms seem to be interchangeable. These two suffixes can only be properly differentiated in the ablative case. However, with verbs assigning accusative or dative case to their SOAarguments, there is considerable difficulty in distinguishing between $-m E K$ and $m E$ forms. Due to these problems I will treat both forms as equal in this paper.

\subsection{Possessive marking}

Complement clauses, except for $-m E k$, can or must be marked with possessive morphology. The possessive marking is a part of the nominal paradigm and is shown in Table 2, taken from Haig (2001). The first paradigm (Type I) appears after the progressive, perfect, aorist and the copula. The second paradigm (Type II) is used with the past tense. The last on (Type III) is used in the optative, imperative and adhortative.

Table 2: The paradigm of possessive marking

\begin{tabular}{|l|c|c|c|c|}
\hline & $\begin{array}{c}\text { possessive } \\
\text { marker }\end{array}$ & $\begin{array}{c}\text { predicate } \\
\text { person marker I }\end{array}$ & $\begin{array}{c}\text { predicate } \\
\text { person marker II }\end{array}$ & $\begin{array}{c}\text { predicate } \\
\text { person marker III }\end{array}$ \\
\hline $1 \mathrm{SG}$ & $-\mathrm{Im} /-\mathrm{m}$ & $-\mathrm{Im} / \mathrm{yIm}$ & $-\mathrm{m}$ & $-\mathrm{yIm}$ \\
\hline $2 \mathrm{SG}$ & $-\mathrm{In} /-\mathrm{n}$ & $-\mathrm{sIn}$ & $-\mathrm{n}$ & $-\varnothing$ \\
\hline $3 \mathrm{SG}$ & $-\mathrm{I} / \mathrm{-sI}$ & $-\varnothing$ & $-\varnothing$ & $-\mathrm{sIn}$ \\
\hline $1 \mathrm{PL}$ & $-\mathrm{ImIz} /-\mathrm{mIz}$ & $-\mathrm{ImIz} /-\mathrm{mIz}$ & $-\mathrm{k}$ & $-\mathrm{yAlIm}$ \\
\hline $2 \mathrm{PL}$ & $-\mathrm{InIz}$ & $-\mathrm{InIz}$ & $-\mathrm{nIz}$ & $-\mathrm{In} /-\mathrm{yIn}$ \\
\hline $3 \mathrm{PL}$ & $-1 \mathrm{ArI}$ & $-1 \mathrm{Ar}$ & $-1 \mathrm{Ar}$ & -sInlAr \\
\hline
\end{tabular}


The possessor marker licenses the realization of the highest argument of the complement predicate. This argument may be realized by a genitive NP, as demonstrated in the example (6). This realization follows the regular genitive pattern found in possessive constructions, where the genitive argument denotes the possessor. If its realization is not possible, because of different processes changing the argument structure, the possessor agreement takes its default value, i.e. $3 \mathrm{SG}$, cf. (10).

$$
\begin{aligned}
& {[\mathrm{Bu} \text { ev-de otur-ul-ma-sin]-1 } \quad \text { isti-yor-um }} \\
& \text { this house-LOC live-PASS-INF-3SG.P-ACC } \\
& \text { 'I want-PROG-1SG } \\
& \text { lit: 'I want that it is lived in this house.' (Haig 1998:37) }
\end{aligned}
$$

The intransitive complement predicate in (10) is in the passive voice. Although the realization of the highest argument is impossible, the possessive morphology is present. In this case the possessor agreement takes the default value, which is 3SG.

The realization of the remaining arguments does not change with the complement predicates. Objects are realized as in verbal sentences, as the examples provided so far demonstrate.

\subsection{Formation of control predicates}

\subsubsection{Derived control predicates}

Many equivalents of English control verbs appear to be derived from non-verbal predicates, cf. Haig (2003) for the discussion of the category-changing processes in the Turkish lexicon. (11) below gives some examples of Turkish control verbs of nominal origin.

$$
\begin{array}{lll}
\text { (11) } \begin{array}{l}
\text { boş 'empty' } \\
\text { zor 'difficulty, necessity' }
\end{array} & \rightarrow & \text { boş-la-mak 'neglect' } \\
\text { çaba 'effort, work' } & \rightarrow & \text { çaba-la-mak 'try, work towards' } \\
\text { baş 'beginning, head' } & \rightarrow & \text { baş-la-mak 'begin' }
\end{array}
$$

In (11) we can see examples of nominal roots turned into verbs. In each case the original noun is still in use and its meaning is provided. In the process of derivation the selectional properties of a predicate may change, i.e. the nouns from which the verbs in (11) are derived do not have to select an SOA-argument.

Furthermore, valency-changing morphology appears inherently on some control predicates in Turkish. Some examples are given in (12).

$$
\begin{array}{lll}
\text { sık 'press' } & \rightarrow & \text { sık-ll-mak (PASS) 'be bored, aggrieved' } \\
\text { çek 'draw, pull' } & \rightarrow & \text { çek-in-mek (REFL) 'avoid' } \\
\text { kalk 'rise' } & \rightarrow & \text { kalk-ış-mak (REC/PASS) 'dare, set out to' }
\end{array}
$$


$\begin{array}{lll}\text { inan 'believe' } & \rightarrow & \text { inan-dir-mak (CAUS) 'persuade' } \\ \text { kan 'believe' } & \rightarrow \quad \text { kan-dir-mak (CAUS) 'persuade' }\end{array}$

As in the case of the category-changing morphology, the stems onto which the valency-changing morphology is applied do not have to take SOA-arguments. This is the case with çek 'draw, pull'.

We can thus see that a considerable number of control verbs in Turkish are of nominal origin, and that these nouns do not have to take SOA-arguments, since in the process of derivation the argument structure of the stems may change.

\subsubsection{Light verb constructions}

Another common way of verb formation involves the use of light verbs, such as etmek 'do' and olmak 'be'. These verbs combine with nominal elements and form complex predicates. Nominal predicates participating in such constructions are often of non-native origin. (13) shows some examples of such light verb constructions. ${ }^{3}$

(13) tercih 'preference' $\rightarrow$ tercih etmek 'to prefer'

ümit 'hope' $\rightarrow$ ümit etmek 'to hope'

$k a b u l$ 'acceptance' $\rightarrow$ kabul etmek 'to accept'

niyet 'plan' $\rightarrow$ niyet etmek 'to plan'

arz 'wish' $\rightarrow$ arz etmek 'to wish'

In contrast to derived control predicates, control verbs resulting from light verb constructions inherit the SOA-argument from the embedded noun. The data in (14) illustrate this. Thus, in light verb constructions the accommodation of a nominal element to the role of a verbal predicate takes place.

$\begin{array}{llll}\text { [Onun Istanbul-a git-me] niyet-in-i } & \text { duy-du-m. } \\ \text { 3SG-GEN Istanbul-DAT go-INF plan-3SG.P-ACC } & \text { hear-PST-1SG } \\ \text { 'I heard of his/her plan to go to Istanbul.' } & \end{array}$

Some variation in the choice of the light verb is possible in a small class of nouns appearing in light verb constructions. The predicates given in (15) may be combined with more than one light verb. Although the translations suggest that they are passive, this is not the case, but at present, no better translation for such predicates seems available.

(15) ikna etmek 'convince'

vs. ikna olmak 'be convinced'

mecbur etmek 'force' vs. mecbur olmak 'be forced'

razl etmek 'convince' vs. razl olmak 'be convinced'

3 Not all nominal predicates in light verb constructions appear independently. 
The variation in the choice of light verb obviously influences the meaning of the predicate. What is more interesting for our purposes, different light verbs apparently influence the control relation of the predicates, cf. (16).
a. Baba-mi
ben- $i_{j}$
ikna et-ti. father-1SG.P 1SG-ACC study-INF-DAT persuade LV-PST.3SG
'My father persuaded me to study.'
b. Ben_i [ _i oku-ma]-ya ikna ol-du-m.
1SG study-INF-DAT persuade LV-PST-1SG
'I am persuaded to study.'

The data above show that the noun ikna 'persuasion' may be combined with two different auxiliaries, etmek 'do', in (16a) and olmak 'be' in (16b). In both cases the complex predicate selects an SOA-argument, i.e. a nominalized infinitive marked for the dative case. The interesting piece of information concerns the choice of the controller. In (16a) the controller of the implied argument of the SOA-argument is an object, i.e. the accusative NP. In (16b), however, it is the subject, i.e. the NP in the nominative. It seems that the noun ikna changes its control properties depending on the choice of the auxiliary. In (16a) we can attest object control, whereas it is subject control in (16b). The same pattern can be observed with mecbur in (17).

$$
\begin{aligned}
& \text { a Baba-m } \left.m_{i} \text { ben- } i_{j} \quad \text { [ }{ }_{j} \text { oku-ma }\right]-y a \text { mecbur et-ti. } \\
& \text { father-1SG.P 1SG-ACC study-INF-DAT force LV-PST.3SG } \\
& \text { 'My father forced me to study.' }
\end{aligned}
$$

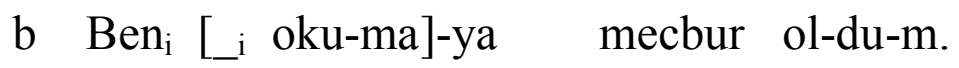

$$
\begin{aligned}
& \text { 1SG study-INF-DAT force LV-PST-1SG } \\
& \text { 'I am forced to study.' }
\end{aligned}
$$

The adverb mecbur takes an SOA-argument with two different light verbs. In (17a) with etmek it behaves like an object control verb, but in (17b) it triggers subject control. Such examples could be treated as control shift but as Barbara Stiebels (p.c.) points out, the apparent shift is only syntactic. Light verbs act differently on the argument structure of the nouns. It seems that with olmak the higher argument is existentially bound, which produces the 'passive' effect.

\section{The domain of control in Turkish}

In section $2 \mathrm{I}$ assumed the distinction between control-inducing and controlneutral structures. In this section I will investigate whether Turkish has a control-inducing structure, and if so, which of the clauses discussed above qualify as such. Furthermore I will investigate the possibility of control in non-controlinducing structures. It will be shown that the nominalized infinitive is not a con- 
trol-inducing structure, in the same sense as are infinitives in languages like German or Polish. It certainly provides a structure which facilitates control most strongly, compared to other types of complements available in this language. However it does not trigger it invariably. Furthermore, obligatory co-reference is marginally possible in non-control-inducing structures. This means that mismatches between the default readings of the complement and the meaning of the matrix verbs are possible, although not very common. The distinction between inherent and structural control proposed here allows the mismatches between the requirements of a matrix verb and the default reading of the complement clause to be explained.

\subsection{Control-inducing and control-neutral structures in Turkish}

The predominant view is that control is possible only in complement clauses with $-m E$ and $-m E K$ forms unmarked for the possessor agreement. ${ }^{4}$ Following this, complements with nominalized infinitives should be control-inducing structures in Turkish. This expectation is indeed met in the majority of cases. However, as has been noticed by Taylan (1996), there are verbs which are clear counter-examples to this prediction. An example of a sentence in which structural conditions for control are met but where no control holds is given in (18).

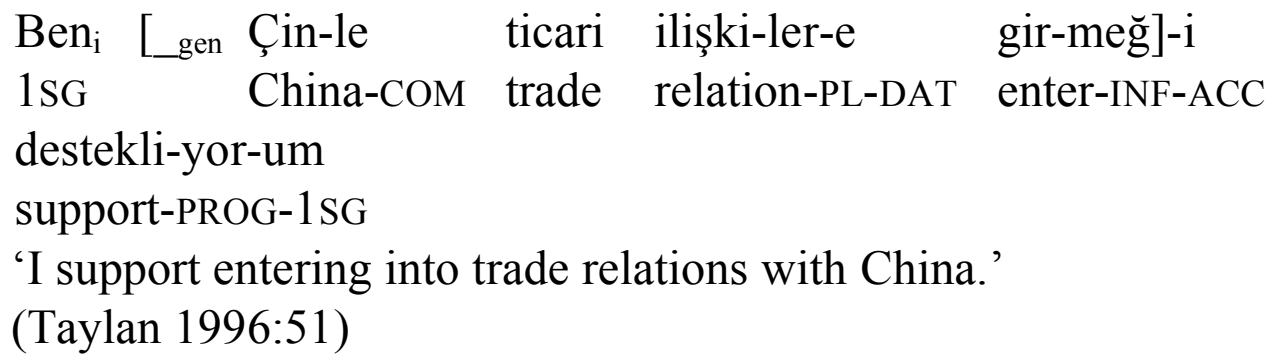

In (18), the SOA-argument is realized by means of the nominalized infinitive girmegi. According to the form of the complement predicate and its function in the sentence, (18) should be a control construction. However, this is not the case. Apparently, the speaker expresses an attitude towards an SOA which does not have to be brought about by him/her. Although the sentence meets the structural criteria for control, the meaning of the matrix predicate does not require it. The data in (18) thus demonstrates that clauses with nominalized infinitives do not provide a control-inducing structure in the strict sense. This kind of complement clause nevertheless provides the structure most appropriate for control in Turkish, and will nevertheless be treated as a control-inducing structure in the following.

4 This view is accompanied by the assumption that only sentential objects may be controlled. This assumption will be reconsidered in the following section. 
The verb desteklemek 'support' is not exceptional with regard to the interpretation of this kind of SOA-argument. Taylan (1996) gives a longer list of predicates following the same pattern. These are repeated in (19) below.

(19) Verbs not triggering control in (nominalized) infinitive complements, following Taylan (1996)

karşı olmak 'be against', desteklemek 'support', doğru bulmak 'find something right', yalnış bulmak 'find something wrong', günah 'consider something immoral', bayllmak 'love', alımak 'get accustomed to', bahsetmek 'talk about', tartışmak 'discuss'

It is interesting to observe that some regularities among the verbs listed above can be observed. There are basically two groups: one group, e.g. desteklemek 'support', günah 'consider something immoral', expresses the attitude of the speaker toward the SOA denoted by the complement predicate. The other group, e.g. bahsetmek 'talk about' and tartışmak 'discuss', refers to the manner of making utterances, and can be regarded as an utterance predicate, cf. (20).

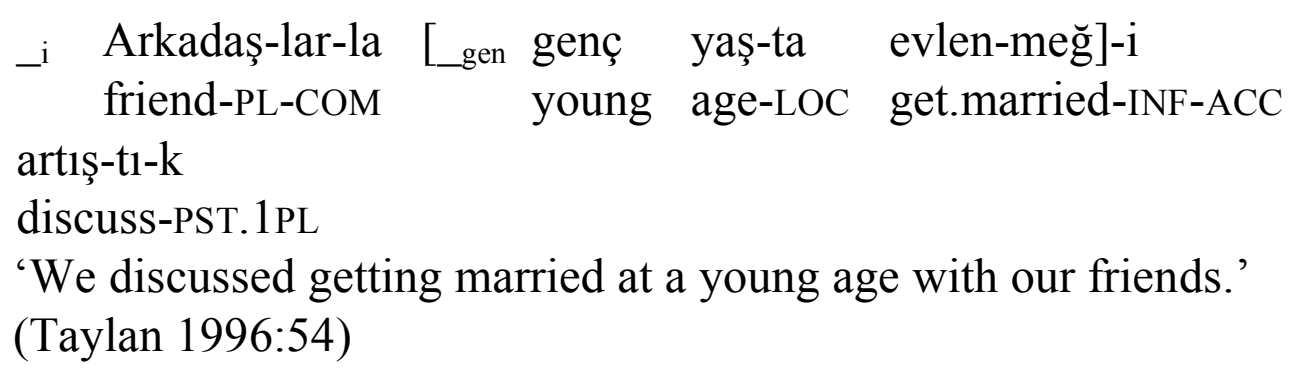

The fact that some matrix verbs do not require control with control-inducing structures is problematic for the approach to control proposed in this paper. Some solutions to this problem are possible. Nominalized infinitive may be regarded as a non-controlling structure and thus all cases of control in Turkish must be regarded as inherent control. This would however miss the fact that inherent control verbs in Polish and Turkish share some similarities. Alternatively, sentences like (18) and (20) could be treated as cases of partial control. This solution is problematic because no partial control is attested otherwise in Turkish. More research is needed to provide a satisfactory answer to this question.

\subsection{Possessor agreement and control}

As Bozşahin (in press: 6) puts it, 'embedded clauses with agreement cannot be targets of control'. This common view, that the possessive morphology on a verbal noun excludes control, is explained by the fact that the possessive agreement licenses the realization of the highest argument in the form of a genitive NP. The possessive morphology turns the embedded clause into a sentence, and the missing pronominal argument cannot bound by an argument of the higher clause. 
Although control is not predicted in such clauses, it must be noted that the interpretation of complements with possessive agreement is not uniform. Depending on the type of the suffix, either an obligatory disjoint reference or an optional co-reference is possible. Let us first consider the interpretation of missing arguments of gerund complements with $-D I K$ and $-E c E K$. As the data in (21) demonstrate, the missing argument may be co-referent with an argument of the higher clause.
a. Ahmet Ayşe-ye $_{j}\left[\_i / j / k\right.$ okul-a git-tiğ/eceğ-in]-i söyle-di.
A. A.-DAT school-DAT go-GER-3SG.P-ACC tell-PST.3SG
'Ahmet told Ayşe that he/she went/will go to school.' (Kural 1998:414)

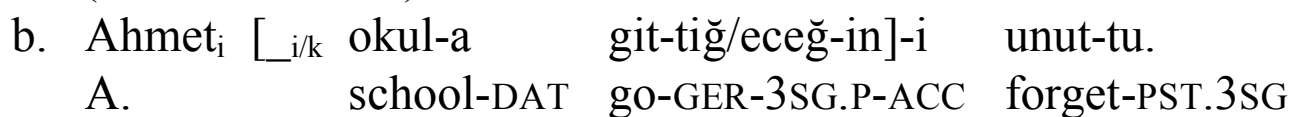

'Ahmet forgot that he/she went/will go to school.' (Kural 1998:414)

In (21a) a three-place SOA-argument-taking verb söylemek 'tell' is given. The complement is a gerund, formed with the suffixes $-D I K$ or $-E c E K$. Although the complement predicate shows the $3 \mathrm{SG}$ possessor agreement, the genitive NP is not present. The indexing shows that the unexpressed argument might be understood as a co-referent with the referent of the matrix subject or object. Although less preferred, the reference to a third participant is also possible. In (21b) with a two-place verb the same pattern can be observed. It can be seen that gerund complements generally allow for a co-reference between their implicit arguments and matrix clause arguments. This co-reference is optional, and will be excluded if the subject of the complement clause is overt.

The influence of the possessive morphology on the interpretation of the unexpressed argument of the $-m A$ complements is slightly different. The data below illustrate the pattern.

$$
\begin{aligned}
& \text { Çocuk }_{\mathrm{i}} \mathrm{k}_{\mathrm{iz}} \mathrm{a}_{\mathrm{j}} \quad\left[\mathrm{L}_{\mathrm{j} / \mathrm{k}}\right. \text { top oyna-ma-sın]-1 söyle-di. } \\
& \text { boy girl-DAT ball play-INF-3SG.P-ACC tell-PST.3SG } \\
& \text { 'The boy told the girl to play ball.' [Özsoy 1987:84] }
\end{aligned}
$$

In (22) the matrix verb söylemek 'tell' takes an SOA-argument headed by the nominalized infinitive oynamasinl, which shows the 3SG possessor agreement. As in the examples above, the genitive NP is missing. This unexpressed argument may be co-referent with the matrix clause object. Again such co-reference is possible only if the argument is implicit.

It has to be noted that the co-reference is possible only with the matrix object. The following example demonstrates that co-reference with a matrix subject is impossible. 
Ahmet $_{i}\left[*_{i} / \mathrm{j}\right.$ Sinema-ya git-me-sin]-i isti-yor.

A. Cinema-DAT go-INF-3SG.P-ACC want-PROG.3SG

'Ahmet wants (him/her) to go to the cinema.' (Kornfilt 1987:112)

In (23) the missing argument of the complement predicate must have a disjoint reference with regard to the matrix clause subject. ${ }^{5}$ It seems that disjoint reference is an invariant property of this kind of construction. This assumption is supported by the following data.
a. Ahmet ${ }_{i}$ [_?ij düş-me-sin-den] kork-uyor-du
A. fall-INF-3SG.P-ABL be.afraid-PROG-PST.3SG
'Ahmet $\mathrm{i}_{\mathrm{i}}$ was afraid that he $\mathrm{e}_{\mathrm{ji}}$ would fall.'
(Haig \& Słodowicz in press)
b. * ben i $_{\mathrm{i}}$ ij düş-me-m-den] kork-uyor-du-m
1SG fall-INF-1SG.P-ABL be.afraid-PROG-PST.1SG
int: 'I was afraid of falling.' (Haig \& Słodowicz in press)

The verb korkmak in the example (24a) may take an $-m E$ SOA-argument with the possessive morphology. Although this sentence is considered to be awkward by some informants, it is important to notice that the $3 \mathrm{SG}$ possessor agreement on the complement predicate must not refer to the matrix subject argument. This becomes even clearer in (24b) with a $1 \mathrm{SG}$ subject. In this example, the complement predicate is also in 1SG, which is supposed to mark the intended coreference. The ungrammaticality of this sentence shows that this is impossible. The data show that with two-place verb, $-m E$ complements with possessor agreement are not control-neutral structures.

The distinction between inherent and structural control postulated in this paper can be demonstrated in a convincing way with the help of this structure. The two-place verb taking an SOA-argument korkmak is a structural control verb. It may select a $-m E$ complement without possessor agreement. In this case it is a subject control verb, as demonstrated in (25).

$\begin{array}{ll}\text { Ahmet }_{i} L_{\mathrm{i}} \text { düş-mek]-ten } & \begin{array}{l}\text { kork-uyor-du. } \\ \text { A. }\end{array}\end{array}$

'Ahmet was afraid to fall.'

The co-reference, which is obligatory in (25), is not inherent to the verb korkmak. This is because this verb may appear with a control-neutral structure, as demonstrated in (24). If complement control were an inherent part of the meaning of this verb, it would either not be able to combine with a control-neutral

5 This pattern strongly resembles the pattern found in Romance languages in complex sentences with subjunctive complements, cf. Kempchinsky (1986) and Farkas (1992). This similarity makes Kornfilt (2003) label nominalized infinitive complements with possessor agreement as subjunctive. 
structure, or would adapt the structure to meet its requirements. Following this, the verb istemek is also a structural control verb, as the comparison of (23) and (26) demonstrates.

(26) Ahmet $_{i}[$ i cinema-ya git-mek] isti-yor.

A. cinema-DAT go-INF want-PROG.3SG

'Ahmet wants to go to the cinema.'

On the other hand, the verb denemek 'try' is an inherent control verb. Since it is a two-place verb taking an SOA-argument, its control properties can be well tested in the control-inducing and control-neutral structure, cf. (27).

a. Ahmet L $_{i}$ i cinema-ya git-me]-yi dene-di.

A. cinema-DAT go-INF-ACC try-PST.3SG

'Ahmet tried to go to the cinema.'

b. * Ahmet ${ }_{i}[$ _ cinema-ya git-me-sin]-i dene-di.

A. cinema-DAT go-INF.3SG.P-ACC try-PST.3SG

In (27a) the missing argument of the complement predicate gitmeyi is an obligatory co-referent with the matrix clause subject; that is to say, this sentence is a control construction. In (27b) the same matrix verb is combined with a controlneutral structure. It is important to note that this sentence is ungrammatical. Apparently the verb denemek 'try' cannot combine with a structure which requires a disjoint reference of the missing argument of the complement predicate and the matrix subject. The ungrammaticality of (27b) must be attributed to the meaning of the matrix verb. Therefore I conclude that the verb denemek 'try' is an inherent control verb, which appears only with the control-inducing structure. It must appear in an environment facilitating control. ${ }^{6}$

Becermek 'manage' is a verb which apparently tolerates such a mismatch. It may combine with the control-inducing and control-neutral structure, hence it is similar to korkmak and not to denemek in this respect. ${ }^{7}$
Ahmet $_{i} L_{-}$
bisiklet-i
tamir et-me-sin]-i
becer-di.
A. bicycle-ACC fixing LV-INF-3SG.P-ACC manage-PST.3SG
'Ahmet managed to fix the bike.' (Haig \& Słodowicz in press)

However, these two verbs are different in some important respects. Whereas korkmak is not an inherent control verb, i.e. the co-reference appears only with the control-inducing structure, becermek is an inherent control verb. Furthermore, in a control-prohibiting structure it will trigger control. The difference between these verbs is further supported by the fact that the former licenses a geni-

6 In the classification which will be elaborated below denemek 'try' will be a strong inherent control verb, cf. section 6.

7 The possessor agreement in such examples can only take the default value, i.e. 3 SG. 
tive NP with a different referent than the matrix clause subject, whereas the latter cannot license such an NP in spite of the possessor agreement, cf. (29).

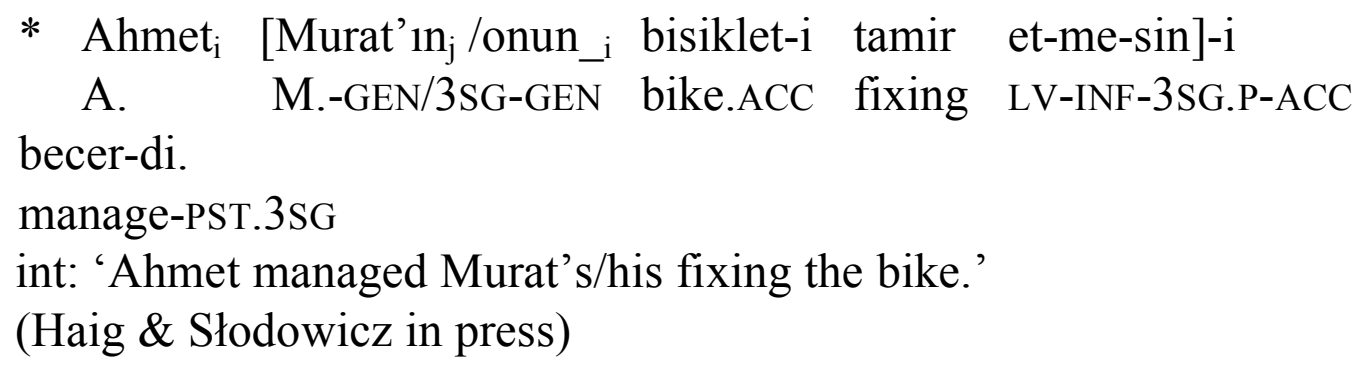

The only conclusion that the above data allows is that the verb becermek 'manage' must be an inherent control verb. In a control-neutral structure it will enforce the obligatory co-reference, but differently to other inherent control verbs like denemek, it may combine with such structures.

The distinction between inherent and structural control proposed in this paper is empirically motivated by the data provided in this section. Moreover, it can explain certain mismatches between the meaning of the verb and the readings of certain types of complement clauses. It therefore provides an improvement to the current approaches to control, for which the data would be problematic

\subsection{Control in sentential subjects}

Another assumption present in the current approach to control pertains to the function of the SOA-argument in a complex sentence. The proposal made by Manzini (1983) predicts that sentential subjects do not involve obligatory control. On the other hand, sentential objects do, when provided with the appropriate form of the complement clause. The second part of this assumption was dealt with in the preceding section. Here I will investigate the interpretation of sentential subjects and, following Stiebels (this volume), will show that sentential subjects of causative experiencer verbs must be obligatorily controlled. The same analysis can be extended to other non-causative predicates taking infinitival sentential subjects. The data will show that sentential subjects also provide a configuration in which obligatory (structural) control may hold. In the following discussion the grammatical relation 'subject' is defined in Turkish as the nominative NP.

The assumption that sentential subjects do not have to be controlled comes from examples like (30).

$$
\begin{aligned}
& \text { [_gen İstakoz-u çiğ ye-mek] sağlığ-a zararlı-dır. } \\
& \text { lobster-ACC raw eat-INF health-DAT damaging-COP.3SG } \\
& \text { 'Eating lobsters raw is a health-hazard.' (Sezer 1986:125) }
\end{aligned}
$$

In (30), the clause with the nominalized infinitive yemek functions as the subject. The missing argument is interpreted generically, which could lead to the 
conclusion that the function of the SOA-argument indeed has some influence on their interpretation. However, the situation changes if the sentence contains a dative argument, as demonstrated in (31).

$$
\begin{aligned}
& \text { [ }{ }_{i} \text { bu viski-yi içmek] hiç iyi ban- } a_{i} \text { gel-me-di } \\
& \text { this whisky-ACC drink-INF not well 1SG-DAT come-NEG-PST.3SG } \\
& \text { 'To drink this whisky was not good for me.' }
\end{aligned}
$$

The interpretation of the missing argument of the complement predicate in (31) is no longer generic. The dative NP must be co-referent with the missing subject of the SOA-argument. This sentence shows that sentential subjects can and in fact must be controlled, if an appropriate argument is present in the matrix clause. We could therefore assume that the experiencer predicates dispose of a dative argument, which is realized when its reference is specific. If this argument is not realized overtly, the argument is interpreted generically. Nevertheless this argument, overt or covert, provides the reference for the missing argument of the complement predicate. The crucial part of this assumption is that the generic interpretation of the missing argument of the complement predicate does not result from the configurational parameters, but from the referential properties of the implied argument of the matrix predicate. Obligatory co-reference holds between it and the missing argument of the complement independently of the referential status of the dative argument. Following this assumption, the example (30) could be analyzed in the following way, cf. Landau (2000) for a similar interpretation of the English data.

$$
\begin{aligned}
& \text { [_gen İstakoz-u çĭ̆ ye-mek] sağlı̆̆-a _ gen zararlı-dır. } \\
& \text { lobster-ACC raw eat-INF health-DAT damaging-COP.3SG }
\end{aligned}
$$

The analysis of control in sentential subjects outlined above could be criticized as too hypothetical. It relies on the assumption that the dative NPs are part of the argument structure of the matrix predicates. However, there is another type of construction in which the controller of sentential subjects is not assumed but motivated by the general pattern of argument linking. In Turkish some experiencer predicates are derived by means of the causative suffixes $-D I r,-I r,-t,-I t$ from predicates which do not necessarily take sentential complements. In (32), some examples of derived experiencer predicates are given.

$$
\begin{array}{ll}
\text { gülmek 'laugh' } & \rightarrow \text { gül-dür-mek 'make laugh' } \\
\text { eğe-len-mek 'amuse' } & \rightarrow \text { eğe-len-dir-mek 'make amused' } \\
\text { heyecan-lan-mak'excite' } \rightarrow \text { heyecan-lan-dır-mak'make excited' }
\end{array}
$$

The application of the causative morpheme changes the argument structure of the target predicate, cf. Comrie (1981:chapter 8) or Kroeger (2004:chapter 8). 
The result of the causative operation on the argument structure of transitive and ditransitive verbs is provided in (33).

$\begin{array}{lcc}\text { Verb } & \text { causer } & \text { causee } \\ \text { intransitive verb e.g. gülmek 'laugh' } & \text { NOM } & \text { ACC } \\ \text { transitive verb e.g. okumak 'read' } & \text { NOM } & \text { DAT } \\ \text { ditransitive verb e.g. koymak 'put' } & \text { NOM } & \text { DAT }\end{array}$

The derived experiencer verbs presented in (32) follow the same pattern of argument linking. Importantly, with these verbs, an SOA-argument can be the causer or the stimulus. In this case, the complement predicate is a nominalized infinitive, as illustrated in (34) below.

[ ${ }_{i} \mathrm{Bu}$ film-i izle-mek] ben- $i_{i}$ çok heyecanlan-dır-di. this film-ACC watch-INF 1SG-ACC much excite-CAUS-PST.3SG 'Seeing this film made me excited.'

In (34) the SOA-argument functions as a subject, i.e. it is in the nominative case (Ø-marking), and the matrix verb shows the default 3SG agreement. According to the configurational approach to control proposed by Manzini (1983), this sentence should not involve obligatory control. However, the interpretation of the arguments is in conflict with this assumption. The unexpressed argument of the complement predicate must be co-referential with the accusative argument of the matrix clause. This sentence is not obsolete. Other derived experiencer verbs in (32) follow the same pattern. The following example likewise shows obligatory control by the causee argument.

$$
\begin{aligned}
& \text { [_i } \mathrm{Bu} \text { haber-ler-i duy-mak] ben- } i_{\mathrm{i}} \text { gül-dür-du. } \\
& \text { this news-PL-ACC hear-INF 1sG-ACC laugh-CAUS-PST.3SG } \\
& \text { 'To hear this news made me laugh.' }
\end{aligned}
$$

(35) clearly shows that control in sentential subjects is possible, and following the assumptions formulated above, even obligatory. In case of the derived experiencer verbs, the missing argument of the complement predicate must be coreferential with the causee. In the case of other verbs taking sentential subjects, it must be co-referential with the dative argument, which may remain implicit if not specific. The relation between this argument and the missing argument of the verbal noun is the same (exhaustive co-reference), regardless of the implicit or explicit realization of the controller. 


\section{The arguments of the control relation}

\subsection{The controllee}

I defined the controllee above as the argument of the complement clause whose reference must be provided by at least one of the matrix clause arguments. The controllees are not overt in Turkish. Furthermore, in Turkish the arguments receiving the default linking (NOM) are controlled, i.e. this language follows the pattern found in other Nominative-Accusative languages.

The choice of the controllee is not dependent on the number of the arguments of the complement predicate. With transitive and intransitive verbs the same argument is controlled. The data in (36) illustrate this.

$$
\begin{aligned}
& \text { a. Çocuk }{ }_{i} \text { anne-sin-e } e_{j} \quad \text { [_i uyu-mağ]-a söz ver-di. } \\
& \text { child mother-3SG.P-DAT sleep.INF-DAT word give-PST.3SG } \\
& \text { 'The child promised his/her mother to sleep.' (Bozşahin in press:6) } \\
& \text { b. Çocuk } k_{i} \text { anne-sin- } i_{j} \quad\left[\_j \text { maksal kitab-1 oku-mağ }\right]-a \\
& \text { child mother-3SG.P-ACC story book-ACC read-INF-DAT } \\
& \text { ikna et-ti. } \\
& \text { persuasion LV-PST.3SG } \\
& \text { 'The child persuaded his/her mother to read a story book.' }
\end{aligned}
$$

The choice of the controllee does not depend on the voice of the complement predicate. In the active and passive voices, the argument of the complement predicate which would receive the nominative case is controlled. This is demonstrated in (37) by the passive form of the complement predicate.

$$
\begin{aligned}
& \text { Köpek }_{i} \text { [_i sev-il-mek] ist-iyor. } \\
& \text { dog pet-PASS-INF want-PROG.3SG } \\
& \text { 'The dog wants to be petted.' (Bozşahin in press:6) }
\end{aligned}
$$

The same holds of the causative morphology, although its application has some results on the control relation. Also with the causative morpheme the argument with the default linker is controlled, cf. (38).

$$
\begin{aligned}
& \text { a. Çocuk [adam-a kitab-1 oku-t-mak] ist-iyor. } \\
& \text { child man-DAT book-ACC read-CAUS-INF want-PROG.3SG } \\
& \text { (Bozşahin in press:7) } \\
& \text { b. Çocuk }{ }_{\mathrm{i}}\left[\mathrm{i}_{\mathrm{i}} \text { adam- } \mathrm{a}_{\mathrm{j}} \text { [_j }_{\mathrm{j}}\right. \text { kitab-1 oku]-t-mak] ist-iyor. } \\
& \text { 'The child }{ }_{i} \text { wants [ }{ }_{i} \text { to have the } \operatorname{man}_{j}\left[L_{j}\right. \text { read the book]]. } \\
& \text { (Bozşahin in press:7) }
\end{aligned}
$$

The data show that the choice of the controllee is constant, regardless of different factors such as transitivity and voice. Thus, the assignment of the controllee seems to be determined by the syntax. The choice of the controllee in Turkish 
presents the purely syntactic aspect of control in this language, cf. Stiebels (this volume). In the following section, the role of the lexicon in control constructions will be discussed.

\subsection{The controller}

The controller has been defined as the argument providing the reference for the controllee. I will show that apart from subject and object control, where the controller is unambiguously selected by the matrix verb, there are cases where the assignment of the controller relies on the context. Furthermore, apart from primary control relations, secondary control relations will be considered. Finally, I will show that split control is possible in Turkish, but partial control is not attested.

\subsubsection{Primary control relations}

Primary control relations do not depend on context and cannot be cancelled. In the following I treat subject, object and variable control as primary control relations. In investigating the control relations I will distinguish between two-place and three-place control verbs.

As far as subject control is concerned, the nominative argument functions as the controller with two-place control verbs. This is demonstrated below in (39) where the subject of the matrix clause, i.e. the nominative NP Ben, controls the reference of the controllee.

$$
\begin{array}{llll}
\text { Ben }_{i} \quad\left[\begin{array}{l}
\text { i } \\
\text { yüz-meğ]-e }
\end{array}\right. & \text { karar } & \text { ver-di-m } \\
\text { 1SG } & \text { swim-INF-DAT } & \text { decision } & \text { take-PST-1SG } \\
\text { 'I decided to swim.' (Taylan 1996:48) }
\end{array}
$$

Although the coding of the controller does not change, the coding of the SOAargument shows considerable variation. Among two-place verbs four different patterns of case marking can be found; these are provided in (40).

(40) Subject control verbs

$$
\text { a. } \lambda \mathrm{P} \quad \lambda \mathrm{x} \quad \mathrm{V}(\mathrm{x}, \mathrm{P}(\mathrm{x}))
$$

DAT NOM

başlamak 'begin', anlaşmak 'agree', ümit etmek 'hope', kabul etmek 'agree', niyet olm. 'plan', karar ver. 'decide', talib olm. 'hope', arzu olm. 'wish', çabalamak 'try', uğraşmak 'accomplish', hakim olm. 'be able', kalkışmak 'set out to', cesaret etmek 'dare', çallşmak 'try'

b. $\lambda \mathrm{P} \quad \lambda \mathrm{x} \quad \mathrm{V}(\mathrm{x}, \mathrm{P}(\mathrm{x}))$

ACC NOM

bitirmek 'complete', hatırlamak 'remember', düssunmek 'think about', boşlamak 'neglect', başarmak 'manage', birakmak 'stop', kesmek 'cut', hak etmek 'deserve', planlamak 'plan', tasarlamak 'consider', 
seçmek 'decide', istemek 'want', tercih etmek 'prefer', reddetmek 'refuse', kasdetmek 'intend', murad etmek 'wish', dilek etmek 'wish', temeni etmek 'wish', beklemek 'wait', halletmek 'complete' becermek 'manage', denemek 'try', unutmak 'forget', ihmal etmek 'neglect'

c. $\begin{array}{llll}\lambda \mathrm{P} & \lambda \mathrm{x} & \mathrm{V}(\mathrm{x}, \mathrm{P}(\mathrm{x}))\end{array}$

ABL NOM

hoşlanmak 'like', hazırlamak 'prepare', korkmak 'fear', sakınmak 'avoid', nefret etmek 'hate', vazgeçmek 'give up' sıkllmak 'be bored', bıkmak 'be bored', kaçmak 'avoid', çekinmek 'refrain'

d. $\lambda \mathrm{P} \quad \lambda \mathrm{x} \quad \mathrm{V}(\mathrm{x}, \mathrm{P}(\mathrm{x}))$

LOC NOM

israr etmek 'insist'

e. $\begin{array}{ccccc}\lambda \mathrm{P} & \lambda \mathrm{y} & \lambda \mathrm{x} & \mathrm{V}(\mathrm{x}, \mathrm{y}, \mathrm{P}(\mathrm{x}))\end{array}$

DAT DAT NOM

söz vermek 'promise'

We can see that the majority of verbs show ACC-NOM linking. The second largest group consists of verbs with DAT-NOM linking. The remaining linking patterns are not very widespread. The ABL-NOM pattern is found predominantly with experiencer verbs; only one verb was attested with the pattern LOC-NOM. Subject control is also possible with the three-place control verb söz vermek 'promise'. This verb exhibits DAT-DAT-NOM linking.

With three-place control verbs, the object may be chosen as the controller; that is, object control holds in this case. In (41) the referent of the matrix clause object, i.e. bana 'me', controls the interpretation of the missing argument of the complement clause.

$$
\begin{aligned}
& \__{i} \text { Ban- }_{j} \quad\left[\_j \text { geri dön-meğ] }-i \quad\right. \text { emret-ti-ler. } \\
& \text { 1SG-DAT back return-INF-ACC command-PST-3PL } \\
& \text { '(They) ordered me to return.' }
\end{aligned}
$$

Transitive verbs triggering object control show some variation in the coding of the controller. I have attested five patterns of case marking, which are given in (42).

(42) Object control verbs

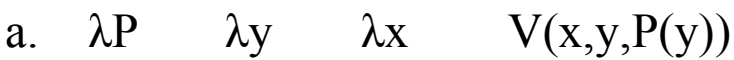

DAT ACC NOM

razl etmek 'convince', zorlamak 'force', mecbur etmek 'force', ikna etmek 'persuade', inandirmak 'persuade', kandırmak 'convince', davet etmek 'request', teşvik etmek 'encourage' müsaade etmek 'allow' 
b. $\lambda \mathrm{P} \quad \lambda \mathrm{y} \quad \lambda \mathrm{x} \quad \mathrm{V}(\mathrm{x}, \mathrm{y}, \mathrm{P}(\mathrm{y}))$

ACC DAT NOM

yardlm etmek 'help', yasaklamak 'forbid', tembih etmek 'warn', rica etmek ' ask', emretmek 'order', söylemek 'say'

$\begin{array}{lllll}\text { c. } & \lambda \mathrm{P} & \lambda \mathrm{y} & \lambda \mathrm{x} & \mathrm{V}(\mathrm{x}, \mathrm{y}, \mathrm{P}(\mathrm{y}))\end{array}$

ACC ABL NOM

taleb etmek 'request'

$\begin{array}{lllll}\text { d. } & \lambda \mathrm{P} & \lambda \mathrm{y} & \lambda \mathrm{x} & \mathrm{V}(\mathrm{x}, \mathrm{y}, \mathrm{P}(\mathrm{y}))\end{array}$

ABL DAT NOM

men etmek 'prohibit'

e. $\begin{array}{lllll}\lambda P & \lambda y & \lambda x & V(x, y, P(y))\end{array}$

ABL ACC NOM

mahrum etmek 'deprive'

Among the object control verbs, the DAT-ACC-NOM (non-canonical) linking is dominant. It is followed by the canonical ACC-DAT-NOM linking found with 7 verbs. I found only one example for the remaining types of argument linking.

So far only unique control readings have been considered. However, there are also control verbs in Turkish that exhibit variable control. As already observed by Taylan (1996) the verb önermek 'propose' is not specific as to the choice of the controller. Depending on the context, either the matrix object, or the matrix subject can be understood as controllers. The data in (43) illustrate this.
Tolga $a_{i}$ Orhan- $a_{j}\left[L_{i} / j o\right.$ binay 1 satın al-măg]-1 öner-di.
T. O.-DAT this building-ACC buy-INF-ACC propose-PST.3SG

'Tolga proposed buying that building to Orhan.' (Taylan 1996)

The missing argument of the complement predicate in (43) can be controlled either by the matrix clause subject, Tolga, or its object, Orhan. According to Taylan (1996) the choice of the controller is dependent on the context of the utterance. Variable control can be also shown with the data in (44). Here the verb tehdit etmek 'threaten' behaves like önermek 'propose' with regard to the choice of the controller.
a. _ $\_$Sen- $i_{j} \quad\left[\_i\right.$ iş-in- $i$
el-in-den
al-mak]-la 2SG-ACC work-2SG.P-ACC
hand-2SG.P-ABL take-INF-COM tehdit edi-yor.
threat LV-PROG-3SG
'She/he is threatening you that she will take away your job.'
b. $\_\mathrm{i}$ Sen- $\mathrm{i}_{\mathrm{j}}$
[ j ev-de kal-mak]-la tehdit edi-yor. 2SG-ACC house-LOC stay-INF-COM threat LV-PROG-3SG 'She/he is threatening you that you will stay at home.' 
The data show the importance of the context in the assignment of the controller with tehdit etmek 'threaten'. (44a) can only be interpreted as a subject control construction. This interpretation is reinforced by the possessive marking on the object of the complement predicate, which makes the matrix object an impossible controller. On the other hand, this verb may also trigger object control, if such an interpretation of the controller is likely. This is shown in (44b).

Not many verbs behave like önermek or tehdit etmek; I was able to attest only three verbs with variable control. These are listed in (45).

Variable control verbs

a. $\lambda \mathrm{P} \quad \lambda \mathrm{y} \quad \lambda \mathrm{x} \quad \mathrm{V}(\mathrm{x}, \mathrm{y}, \mathrm{P}(\mathrm{x} / \mathrm{y}))$

ACC DAT NOM

önermek 'propose', teklif etmek 'propose'

b. $\lambda \mathrm{P} \quad \lambda \mathrm{y} \quad \lambda \mathrm{x} \quad \mathrm{V}(\mathrm{x}, \mathrm{y}, \mathrm{P}(\mathrm{x} / \mathrm{y}))$

$\mathrm{COM}$ ACC NOM

tehdit etmek 'threaten'

\subsubsection{Secondary control relations}

Secondary control relations occur in non-neutral contexts and can be cancelled. These contexts involve, for instance, the use of collective predicates. Following this, split and partial control are secondary with respect to subject, object and variable control. The reason to treat these as secondary is that every so far predicate allowing for a secondary control relation will invariably show a primary control relation in a neutral context; in other words, I did not attest any verbs which would invariantly trigger split or partial control. In this section, I will show that Turkish seems to have split but lacks partial control.

In split control, both matrix clause arguments are understood as controllers. A regular test for this control relation involves the embedding of verbs denoting activities that can be carried out collectively, which can be additionally modified by expressions such as 'together'. The Turkish equivalents of 'meet' involve the reciprocal affix -Iş, cf. Kornfilt (1997:159). Some examples are given in (46).

$$
\begin{array}{ll}
\text { gör-mek 'see' } & \rightarrow \text { gör-üş-mek 'see each other', 'meet' } \\
\text { bul-mak'find' } & \rightarrow \text { bul-uş-mak'find each other', 'meet' } \\
\text { karşı-la-mak 'encounter' } \rightarrow \text { karşı-laş-mak 'meet' }
\end{array}
$$

The collective predicates presented above require a subject that either refers to a group of participants or an additional argument referring to a further participant involved in the SOA. The data in (47) show that buluşmak 'meet' has the required properties. 
a. Ahmet dün Ayşe-ile park-da bu-luş-tu.

A. yesterday A.-COM park-LOC find-REC-PST.3SG

'Ahmet met Ayşe yesterday in the park.'

b. Ahmet ve Ayşe park-da buluş-tuk

A. and A. park-LOC find-REFL-PST.1PL

'Ahmet and Ayşe met yesterday in the park.'

Example (47a) shows that the verb buluşmak 'meet' requires two arguments, one in the nominative, the other in the comitative. Alternatively in (47b), one argument referring to a group of participants is also possible.

Now we can turn to sentences in which such collective predicates are embedded. I will start with an analysis of three-place control verbs. The data below illustrate the behaviour of the matrix verb ikna etmek 'persuade' selecting buluşmak as its complement.
a. Ahmet ${ }_{i}$ Ayşe-yi $_{j} \quad\left[{ }_{i+j}\right.$ cinema-da bul-uş-ma $]-y a$ ikna
A. A.-DAT cinema-LOC find-REC-INF-DAT persuasion et-ti.
LV-PST.3SG

'Ahmet persuaded Ayşe to meet in the cinema.'

b. Ahmet ${ }_{i}$ Ayşe-yi $i_{j}\left[{ }_{j} / i+j\right.$ Bülent-ilek cinema-da bul-uş-ma $]$-ya
A.
A.-DAT
B.-COM
cinema-LOC find-REC-INF-DAT
ikna et-ti.
persiasion LV-PST.3SG
'Ahmet persuaded Ayşe to meet in the cinema with Bülent.'

The control verb ikna etmek 'persuade' may take the verb buluşmak 'meet' as its complement. Moreover, we can see that the complement clause in (48a) does not contain any argument in the comitative, and it has been shown that this is only possible if the subject refers to a group of participants, cf. (47b). Rejecting, for the time being, the assumption that there are further implicit arguments in the complement clause, the conclusion is that the missing argument of the complement predicate must refer to a group of participants, namely Ahmet and Ayşe, which are the referents of both arguments of the matrix clause, hence we have split control. In (48b) the second argument of the complement, the predicate is present. In this case, the primary control relation, i.e. object control, is the first choice, but the split reading is still possible. This kind of behaviour by ikna etmek 'convince' is not exceptional, and can be found with many other verbs as well. Split control therefore seems to be widely available in Turkish. ${ }^{8}$

8 I emphasize that this analysis rejects the assumption that there are additional implicit arguments in the complement clause. In Słodowicz (2006) I have shown that similar con- 
What happens if collective predicates are embedded under two-place control verbs? If such embedding were possible, we could attest partial control because the collective reading of the missing complement argument can only be maintained by inclusion of referents that are not exhaustively provided by the argument of the matrix verb, cf. Landau (2000). Consider now the data in (49).

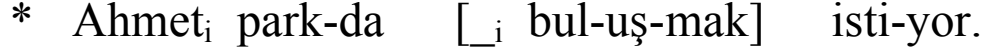

$$
\begin{aligned}
& \text { A. park-LOC find-REFL-INF want-PROG.3SG }
\end{aligned}
$$

'Ahmet wanted to meet in the park.'

It is not possible for the verb istemek 'want' to embed a collective predicate with a semantic plural subject, which clashes with the requirement of the complement predicate. ${ }^{9}$ It thus seems that Turkish does not have partial control. This assumption is supported by the data in which the verb toplanmak, another collective predicate that may be used to test for partial control in Turkish, is used, cf. $(50){ }^{10}$

$$
\begin{aligned}
& \text { a. * Ben toplan-d1-m. } \\
& \text { 1SG gather-PST-1SG } \\
& \text { '*I gathered.' }
\end{aligned}
$$

b. Biz toplan-di-k.

1PL gather-PST-1PL

'We gathered.'

The data in (50) show that this verb provides a good test for partial control. The data in (51) demonstrate the behaviour of the control verb istemek 'want', selecting toplanmak as its complement predicate. The data are representative of the rest of the two-place control verbs in the corpus.
a. * $\operatorname{Ben}_{\mathrm{i}}\left[\mathrm{i}_{\mathrm{i}+\mathrm{k}}\right.$ toplan-mak] iste-di-m. 1SG gather-INF want-PST-1SG 'I wanted to gather.'
b. Biz ${ }_{i} L_{-i}$ toplan-mak] iste-di-k.
$1 \mathrm{PL} \quad$ gather-INF want-PST-1PL
'We wanted to gather.'

The sentence (51a) shows that istemek does not allow for a partial control reading with tomplanmak as its complement. However a combination of these two predicates is possible, as shown in $(51 \mathrm{~b})$. The data shows that the ungrammati-

structions in Polish may be analyzed differently without restoring to the notion of split control.

9 It must be noted that the ungrammaticality of (49) does not result from some more general constraint on the embedding of collective predicates as is shown below.

10 The verb toplanmak has other readings, such as 'pack one's things', 'add' or 'gain on weight', which are not relevant here. 
cality of sentences like (51a) must be attributed to a general lack of partial control in Turkish, and not to some prohibition against embedding of collective predicates.

\section{Classification of control verbs}

Up to this point we have established the domain of structural control in Turkish. Additionally we have seen that there are cases, albeit not very numerous, in which control holds in control-neutral structures. In the next stage I will investigate the distribution of control verbs among the classes of inherent and structural control. First, however, I will outline the classification of control verbs as proposed by Stiebels (this volume).

\subsection{The system for classification}

Stiebels (this volume) proposes four classes of control verbs, each of which is defined by means of two features. The first feature is the sub-categorization properties of a verb. Here, a distinction between control-inducing and controlneutral structures provides three classes of verbs. Verbs selecting control-neutral structures are further divided into verbs controlling such structures and verbs which show no control. The classification of control verbs as proposed by Stiebels is given in Table 3 .

Table 3: Classification of control verbs following Stiebels (this volume)

\begin{tabular}{|l|c|cc|}
\hline & \multicolumn{2}{|c|}{ Control-inducing } & \multicolumn{2}{|c|}{ Control-neutral } \\
\hline Strong inherent control & $\sqrt{ }$ & $*$ & \\
\hline Weak inherent control & $\sqrt{ }$ & $\sqrt{ }$ & + control \\
\hline Structural control & $\sqrt{ }$ & $\sqrt{ }$ & -control \\
\hline Marked inherent control & $*$ & $\sqrt{ }$ & + control \\
\hline
\end{tabular}

Strong inherent control verbs only appear with control-inducing structures. Weak inherent control verbs combine with control-inducing and neutral structures. With both structures they require control. Structural control verbs may appear with control-inducing and neutral structures. Whereas control obtains with the former, no control reading is required with the latter. Quite exceptional are verbs which only combine with control-neutral structures but nevertheless trigger control in them, e.g. marked inherent control verbs.

To this general classification of control verbs further refinements can be added. Stiebels (this volume) suggests introducing a distinction of verbs selecting sentential subjects and those selecting sentential objects. Further modifications in the same vein are possible. Additional classes may be proposed for subject, object and variable control verbs. 


\subsection{Classes of control verbs in Turkish}

Adopting the above system of classification, a corpus of 78 verbs selecting SOA-arguments has been analysed. Although classes strong, weak inherent and structural control verbs are attested, no verb showed marked inherent control. Non-control verbs were established, but they will not be considered here. In the following, I will briefly present the classes of control verbs and provide lists of verbs falling into them.

\subsubsection{Strong inherent control}

Zorlamak 'force' is an example of a strong inherent object control verb. This verb allows for $-m E$ complements which cannot be marked for the possessor agreement. Furthermore, this verb does not select gerundial complements, cf. (52).

(52) Ahmet $_{\mathrm{i}}$ Ayşe-yi $\mathrm{i}_{\mathrm{j}}$ L $_{j}$ İstanbul'a git-me/*-sin/*eceğ-in]-e

A. A.-ACC I.-DAT go-INF $/ *^{*} 3 \mathrm{SG} . \mathrm{P} /{ }^{*}$ GER-3SG.P-DAT

zorladi.

force-PST.3SG

'Ahmet forced Ayşe to go to Istanbul.'

The data in (52) show that zorlamak 'force' is a strong inherent control verb. It allows only for the control-inducing structure, and does not tolerate any controlneutral structure. 26 verbs in my corpus show strong inherent control. Slightly more than half of them (15) show subject control, whereas 11 trigger object control. Strong inherent object control verbs in Turkish select sentential objects, i.e. no control of sentential subjects was attested. Subject and object control verbs show different argument linkings, e.g. ACC-NOM with kesmek 'cut, stop', but DAT-NOM with callşmak 'try, work toward'; in other words, no correlation can be established between the argument linking and control properties.

The strong inherent control verb zorlamak is a manipulative verb. In fact, all other object control verbs in this class express strong manipulation. As for subject control verbs, they tend to be modal, phase and implicative verbs. Some verbs cannot be definitely classified. Verbs such as reddetmek 'refuse' show a desiderative component, and are implicative at the same time. This points to serious drawbacks in the current classifications of verbs taking SOA-arguments. Notwithstanding these difficulties, strong inherent control verbs seem to constitute a homogeneous classes, if a distinction in subject and object control verbs is made. (53) provides a list of strong inherent control verbs.

(53) Verbs with strong inherent control

a. Subject control

çalışmak 'try, work towards', vazgeçmek 'give up', çekinmek 'refrain', boşlamak 'neglect', kesmek 'cut, stop', hakim olm. 'master, be 
able' reddetmek 'refuse', ihmal etmek 'neglect', sakınmak 'avoid', halletmek 'manage' çabalamak 'try', uğraşmak 'accomplish', denemek 'try', kalkışmak 'set out to' cesaret etmek 'dare'

b. Object control

mahrum etmek 'deprive', davet etmek 'request' zorlamak 'force', mecbur etmek 'force', yasaklamak 'ban', men etmek 'prohibit' ikna etmek 'persuade' emretmek 'order' teşvik etmek 'encourage' taleb etmek 'request' yardim etmek 'help'

\subsubsection{Weak inherent control}

Verbs with weak inherent control select control-inducing but also tolerate control-neutral structures. In the latter they trigger control, which shows that obligatory co-reference is an inherent part of their meaning. Becermek 'manage', already discussed above, shows such properties. (28), repeated below, illustrates this.

$\begin{array}{lllll}\text { Ahmet }_{i}[\mathrm{i} \text { bisiklet-i } & \text { tamir } & \text { et-me-sin]-i } & \text { becer-di. } \\ \text { A. } & \text { bicycle-ACC } & \text { fixing } & \text { LV-INF-3SG.P-ACC } & \text { manage-PST.3SG }\end{array}$

'Ahmet managed to fix the bike.' (Haig \& Słodowicz in press)

The matrix verb in (28) may select for a nominalized infinitive (preferably) without possessor agreement. If a possessor agreement is present, obligatory coreference holds between the matrix subject and the implied argument of the complement predicate. Other types of SOA-arguments are not possible with this verb.

The number of weak inherent control verbs in Turkish is quite small; only 6 verbs could be attested in this class. All these verbs select sentential objects and show subject control. Interestingly, the argument linking is not constant among these verbs, e.g. DAT-NOM with beçermek and ACC-NOM with başlamak, hence once again no correlation between argument linking and control properties can be established. Weak inherent control verbs show similar meanings to strong inherent ones, i.e. they are implicative and phase verbs. The list of verbs belonging to this class is given in (54).

(54) Verbs with weak inherent control

Subject control

becermek 'manage', başlamak 'begin', kaçmak 'avoid' bitirmek 'complete' başarmak 'manage' birakmak 'stop'

\subsubsection{Structural control}

The verb önermek 'propose' is a verb with structural control. The data in (55) demonstrate the control properties of this verb. 
(55) a. Ayşe $\mathrm{i}_{\mathrm{i}}$ Ahmet- $\mathrm{e}_{\mathrm{j}}\left[\mathrm{L}_{\mathrm{i} / \mathrm{j}}\right.$ alışveriş yap-mağ $]-1$ öner-di.

A. A.-DAT shopping do-INF-ACC propose-PST.3SG

'Ayşe proposed doing the shopping to Ahmet.'

b. Ayşe Ahmet-e [Murad-ın alışveriş yap-ma-sin]-1

A. A.-DAT [M.-GEN shopping do-INF-3SG.P-ACC

öner-di.

propose-PST.3SG

'Ayşe proposed to Ahmet that Murad should do the shopping.'

Clearly, the verb önermek 'propose' is not an inherent control verb. It selects a nominalized infinitive complement which may be marked with possessive morphology. In (55a) we can see a complement without possessor agreement. In this case, obligatory co-reference with one of the matrix clause arguments must obtain. In (55a) the complement bears possessor agreement. In this case a genitive NP, referring to the agent of the SOA denoted by the complement predicate, is allowed. This shows that (55b) is not a control construction.

(57) Verbs with structural control

a. Subject control

israr etmek 'insist', dilemek 'wish' sikılmak 'be bored', bıkmak 'be bored', hatırlamak 'remember', düşünmek 'think about', hak etmek 'deserve', planlamak 'plan', tasarlamak 'consider', seçmek 'decide', istemek 'want', tercih etmek 'prefer', hoşlanmak 'like', hazırlamak 'prepare', anlaşmak 'agree', ümit etmek 'hope', korkmak 'be afraid', kabul etmek 'agree', niyet etmek 'plan', karar etmek 'decide', talib olm. 'hope', unutumak 'forget', nefret etmek 'hate'

b. Object control

tembih etmek 'warn', inandirmak 'persuade', kandirmak 'convince', söylemek 'tell', müsaade etmek 'allow', heyeçanladırmak 'excite', ĕgelendirmek 'amuse', güldürmek 'make laugh' hüzün 'sadden', söz ver. 'promise', razl etmek 'convince'

c. Variable control

önermek 'propose', teklif etmek 'propose', tehdit etmek 'threaten'

\subsection{Evaluation}

The first observation concerns the linking of matrix clause arguments of control verbs and its relevance for control. The results of the analysis show that control is not dependent on any particular linking. Although canonical linkings (ACCNOM, ACC-DAT-NOM) are represented by large classes of verbs, non-canonical coding of arguments is also possible. In the corpus we find controllers and SOAarguments receiving non-canonical, semantic linking. This indicates that inherent and structural control do not depend on argument linking. 
Secondly, not all primary control relations are equally distributed among the verbs in the corpus. In particular, variable control is found only with structural control verbs. Subject and object control, on the other hand, are attested with inherent and structural control verbs. With these control relations, we observe that there are no correlations between the control relation and structural and inherent control.

Thirdly, it is important to note that although strong and weak inherent control verbs and structural control verbs are attested, no examples of marked inherent control verbs are available. Perhaps this is due to the limited size of the corpus tested. Until no further evidence becomes available, I am forced to assume that Turkish lacks this type of control verbs.

Inherent and structural control verbs show similar meanings. Inherent control verbs tend to belong to the classes of modal, phasal, implicative and (strong) manipulative verbs. On the other hand, desiderative, propositional-attitude and utterance verbs may only function as structural control verbs. This observation shows that the lexical semantics of matrix verbs is an important factor influencing the control properties.

Similar claims have been made in the past, cf. Givón (1980), Croft (2001), Cristofaro (2003) and Van Valin (2005). Approaches claiming that there is a close connection between verb semantics and its control properties rely on 'situational' classifications of such verbs. These try to predict how particular classes of verbs behave with regard to certain phenomena, control being one of them. However, there are some disadvantages to such approaches. One of them is the empirical inadequacy of the classifications they apply. Most importantly, verbs are expected to be unambiguously classified as either phasal, manipulative or propositional-attitude verbs. However, this is often not the case, as the discussion of the derived experiencer verbs in section 4.3 demonstrated. These verbs fall into (at least) two classes; they are propositional-attitude and manipulative verbs at the same time. Such multiple class membership is a central problem for the approaches mentioned above.

Another problem arises from the assumed iconicity between the meaning of the verb and the form of the SOA-argument it selects. Although Turkish seems to be a good example for this assumption, i.e. as we have seen the class of weak inherent control verbs is rather small, not all languages comply with it. In Polish, as shown in my earlier work (2006), the class of weak inherent control verbs is considerably larger, and therefore the idea of an iconic relationship has to be considered more critically.

Regardless of the problems with the current typological classifications of verbs selecting SOA-arguments, the predictions they make largely agree with the results of my analysis. Modal, phasal and implicative verbs show inherent control as expected. The same is true of strong manipulative verbs. Verbs which 
are not expected to involve inherent control cluster around the classes of propositional-attitude and utterance verbs. The difference between the classification conducted here and those proposed by Givón (1980) or Cristofaro (2003) is that the former established the classes explicitly and unambiguously, whereas the latter only assumes them and cannot classify the verbs without restoring speculations.

\section{Summary}

This paper has demonstrated that complement control in Turkish is a mixed syntactico-semantic phenomenon. The obligatory co-reference of two arguments in a complex sentence consisting of a matrix and a complement clause may arise through the lexical specifications of the matrix verb, or through the structural requirements of a particular form of the complement predicate. These two kinds of control have been termed 'inherent' and 'structural' control.

The semantic approach to control proposed here differs considerably from the currently well-established and configurationally-determined approaches to control in Turkish in some important points. Although the form of the complement predicate has been recognized as an important factor here, I have claimed that it does not fully determine control. Instead, following Stiebels (this volume), I proposed distinguishing between control-inducing and control-neutral structures. Control inducing structures are found predominantly in control constructions. As we have seen, however, exceptions are possible and control can also be found in control-neutral structures. Therefore an approach not assuming a strict connection between the form and function is superior to any approach relying on a oneto-one dependency. The approach proposed here does not restrict control to a particular form of complement clause.

In the configurational approaches, the function of the SOA-argument is expected to be relevant for control. Although sentential subjects are expected not to involve obligatory control, I have shown data which proves the opposite. Additionally, the data that has been used so far to argue for generic interpretation of the missing argument of the complement clause should receive a different analysis. The alternative analysis proposed here allows for a coherent treatment of embedded nominalized infinitives.

This paper has postulated a distinction between inherent and structural control. It has also provided a classification of control verbs which shows that such a distinction is empirically relevant. Although it is difficult to give an exhaustive list of control verbs in Turkish, partly because of the quite productive pattern of their formation, an analysis of a sample of such verbs showed that predicates are not distributed randomly between the classes of inherent and structural control. Inherent control verbs are usually found among modal, phasal, implicative and 
strongly manipulative verbs. Propositional-attitude and utterance verbs, on the other hand, tend to show structural control. These results allow predictions to be made regarding those verbs which are not included in the sample. It is expected that any verb with a meaning component denoting modality, a phase of the embedded SOA, its implication or manipulation is likely to show inherent control. Consequently, verbs denoting attitudes and acts of utterance may only function as structural control verbs.

The results presented here are in accord with the analysis of control predicates in other languages such as Polish (Słodowicz 2006). However, still more cross-linguistic evidence is needed in order to draw firm conclusions about the distribution of control verbs. Nevertheless some preliminary conclusions can be made. In comparison with Polish, Turkish is a language where little mismatch between the lexical specifications of the matrix verbs and the readings of the different types of complement clauses is allowed. There is only a small class of verbs belonging to class B. In contrast, Polish allows such mismatches on a larger scale. It is a matter of further research to explain these differences.

\begin{tabular}{ll|ll} 
Abbreviations \\
1 & first person & LOC & locative \\
2 & second person & LV & light verb \\
3 & third person & NEG & negation \\
ABL & ablative & NOM & nominative \\
ACC & accusative & P & possessive \\
CAUS & causative & PASS & passive \\
COM & comitative & PL & plural \\
COP & copula & PROG & progressive \\
DAT & dative & PST & past \\
GEN & genitive & REC & reciprocal \\
GER & gerund & REFL & reflexive \\
INF & infinitive & SG & singular \\
INST & instrumental & &
\end{tabular}

\section{References}

Boeschoten, Hendrik E. \& Ludo Th. Verhoeven (eds.)(1987). Studies in modern Turkish. Proceedings of the third conference on Turkish linguistics. Tilburg: Tilburg University Press.

Bozşahin, Cem (in press). On the Turkish controllee. Proceedings of the 12th Conference on Turkish Linguistics. 
Comrie, Bernard (1981). Language Universals and Linguistic Typology. Oxford: Blackwell.

Cristofaro, Sonia (2003). Subordination. Oxford Studies in Typology and Linguistic Theory. Oxford: Oxford University Press.

Croft, William (2001). Radical Construction Grammar. Syntactic Theory in Typological Perspective. Oxford: Oxford University Press.

Culicover, Peter W. \& Ray S. Jackendoff (2005). Simpler syntax. Oxford: Oxford University Press.

Farkas, Donka (1992). On Obviation. In: Ivan A. Sag \& Anna Szabolcsi (eds.), Lexical Matters. Stanford California: CSLI, 85-110.

Gamerschlag, Thomas (this volume). Semantic and Structural Aspects of Complement Control in Korean.

Givón, Talmy (1980). The binding hierarchy and the typology of complements. Studies in Language 4, 333-377.

Göçmen, Elvan, Onur Şehitoğlu \& Cem Bozşahin (1995). An Outline of Turkish Syntax. Ms. Department of Computer Engineering.

Haig, Geoffrey (1998). Relative Constructions in Turkish. Wiesbaden: Harrasowitz.

Haig, Geoffrey (2001). Word-class distinctions and morphological type: agglutinating and fusional languages reconsidered. Ms., University of Kiel.

Haig, Geoffrey (2003). From lexical class to syntactic function: A sketch of Turkish word structure. In: S. Özsoy et al. (eds.), Studies in Turkish Linguistics. Proceedings of the 10th International Conference on Turkish Linguistics, 2000. Istanbul: Bogaziçi Üniversitesi Press, 59-68.

Haig, Geoffrey \& Szymon Słodowicz (in press). Control in Turkish non-finite complements. In: Proceedings of the 12th International Conference on Turkish Linguistics, 2004.

Hornstein, Norbert (1999). Movement and control. Linguistic Inquiry 30, 69-96.

Kempchinsky, Paula (1986). The Subjunctive Disjoint Reference Effect. In: Carol Neidle \& Rafael A. Nuñez Cedaño (eds.), Studies on Romance Languages. Dordrecht: Foris, 123140.

Kerslake, Celia (1987). Noun phrase deletion and pronominalization in Turkish. In: Hendrik E. Boeschoten \& Ludo Th. Verhoeven (eds.), 91-104.

Kornfilt, Jaklin (1987). Beyond Binding Conditions: The Case of Turkish. In: Hendrik E. Boeschoten \& Ludo Th. Verhoeven (eds.), 105-120.

Kornfilt, Jaklin (2003). Subject Case in Turkish nominalized clauses. In: Luka Szucsich \& Uwe Junghans (eds.), Syntactic Structures and Morphological Information. Berlin: Mouton de Gruyter, 129-215.

Kornfilt, Jaklin (1997). Turkish. London: Routledge.

Kroeger, Paul R. (2004). Analyzing Syntax. A Lexical-Functional Approach. Cambridge: Cambridge University Press.

Kural, Murat (1998). Subordinate Infls and Comp in Turkish. In: Lars Johanson (ed.), The Mainz meeting: Proceedings of the 7th International Conference on Turkish Linguistics, 1994. Wiesbaden: Harrassowitz, 404-421. 
Landau, Idan (2000). Elements of control. Dordrecht: Kluwer.

Lewis, Geoffrey $\left(2000^{2}\right)$. Turkish grammar. Oxford University Press.

Manzini, Rita (1983). On control and control theory. Linguistic Inquiry 14, 421-446.

Özsoy, Sumru (1987). The null subject parameter and Turkish. In Hendrik E. Boeschoten \& Ludo Th. Verhoeven (eds.), 82-90.

Özsoy, Sumru A. (2001). On 'small' clauses, other 'bare' verbal complements and feature checking in Turkish. In: Eser Erguvanlı Taylan (ed.), The Verb in Turkish. Amsterdam: John Benjamins, 213-237.

Polinsky, Maria \& Eric Potsdam (2002). Backward Control. Linguistic Inquiry 33, 245-282.

Sezer, Engin (1986). The unmarked sentential subject constraint in Turkish. In: Dan Slobin \& Karl Zimmer (eds.), Studies in Turkish Linguistics. Amsterdam: John Benjamins, 123135.

Sezer, Erol (1981). The k/Ø alternation in Turkish. In: G. Clements (ed.), Harvard Studies in Phonology 2. Bloomington: Indiana University Linguistics Club, 354-382.

Słodowicz, Szymon (2006). Control in Polish Complement Clauses. Unpublished doctoral dissertation. CAU University of Kiel.

Stiebels, Barbara (this volume). Towards a typology of complement control.

Taylan, Eser (1984). The function of word order in Turkish grammar. Berkeley Los Angeles: University of California Press.

Taylan, Eser (1996). Aspects of control in Turkish. In: Rona Bengisu (ed.), Current issues in Turkish linguistics: Proceedings of the 5th International Conference on Turkish Linguistics, 1990. Ankara: Hitit, 46-60.

Van Valin, Robert D. (2005). Exploring the Syntax-Semantics Interface. Cambridge: Cambridge University Press.

Williams, Edwin (1980). Predication. Linguistic Inquiry 11, 203-238. 